\title{
Investigation of the effects of probiotics on allergy
}

\author{
Probiyotiklerin alerji üzerine etkisinin araştırılması
}

\author{
Rabia Can SARINOĞLU, Buket CİCİĞLU ARIDOĞAN
}

\section{ABSTRACT}

Objectives: To investigate the effects of a probiotic mixture that was isolated from human gut flora, and a standard probiotic strain Lactobacillus $G G$ (LGG) on allergic immune responses in an animal model.

Materials and Methods: Three Enterococcus faecalis, 8 Lactobacillus plantarum, and 2 Lactobacillus rhamnosus strains were included in the mixture. Balb-c mice in the study groups were given the probiotic mixture, and standard strain LGG, and animals in the control groups were given skimmed milk for 28 days. The mice in the study groups and the positive control group were immunized with an intraperitoneal injection of ovalbumin (OVA) on days 14 and 21. An enzyme-linked immunosorbent assay was used to study the OVA-specific IgE levels in the mice serums.

Results: The most remarkable results were that OVAspecific IgE levels were significantly higher $(P<0.001)$ in the positive control group compared with the nonimmunized negative control group, and OVA-specific IgE levels in the study groups were significantly lower than the positive control group $(P<0.001)$.

Conclusion: The data of the present study suggest that oral administration of probiotics prevents IgE-mediated OVAhypersensitivity; however, the immunoregulatory effects of strains must be described in detail while preparing probiotic mixtures.

Keywords: Probiotics, Hypersensitivity, Lactobacillus

Rabia Can Sarınoğlu (局

Department of Medical Microbiology, School of Medicine, Marmara University Pendik Training and Research Hospital, Istanbul, Turkey mail:rabiacansarinoglu@hotmail.com

Buket Cicioğlu Arıdoğan

Department of Medical Microbiology, School of Medicine, Süleyman Demirel University, Isparta, Turkey

Submitted / Gönderilme: 30.05.2017
ÖZ

Amaç: Bu çalışmada, insan bağırsak florasından izole edilerek tanımlanan Lactobacillus spp. ve Enterococcus spp. suşlarından hazırladığımız probiyotik karışım ve standart probiyotik suş Lactobacillus $G G$ (LGG)'nin alerjik immün cevaplar üzerine etkilerinin hayvan modelinde araştırılması amaçlanmıştır.

GereçveYöntem:ProbiyotiknitelikleritanımlananüçEnterococcus faecalis, sekiz Lactobacillus plantarum ve iki Lactobacillus rhamnosus suşu, probiyotik karışıma alınmıştır. Çalışma gruplarındaki Balb-c fareler probiyotik karışım ve standart suş LGG, kontrol gruplarındaki fareler ise skim milk ile 28 gün boyunca beslenmiştir. Çalışma grupları ve pozitif kontrol grubundaki fareler 14. ve 21. günlerde ovalbumin (OVA)'nın intraperitoneal enjeksiyonu ile immünize edilmiştir. Negatif kontrol grubuna fosfat tamponlu su enjekte edilmiştir. Fare serumlarında OVA spesifik IgE düzeyleri ELISA yöntemi ile çalışılmıştır.

Bulgular: En dikkat çekici sonuçlarımız; hayvan deneyinde OVA ile immünizasyon yapılan pozitif kontrol grubunda negatif kontrol grubu ile karşılaştırıldığında OVA spesifik IgE düzeylerinin anlamlı olarak yüksek bulunması $(P<0.001)$ ve probiyotik karışım ve standart suş uygulanan çalışma gruplarının OVA spesifik IgE düzeylerinin sadece skim milk ile beslenen pozitif kontrol grubuna göre anlamlı olarak düşük bulunmasıdır $(P<0.001)$.

Sonuç: Buçalışmanınverileri, probiyotiklerin oraluygulanmasının IgE aracılı OVA hipersensitivitesini engelleyebileceğini göstermiştir, fakat probiyotik karışımlar hazırlanırken kullanılacak probiyotik nitelikli kökenlerin alerji üzerine olan immünoregülatör etkilerinin ayrıntılı bir şekilde tanımlanması gerektiğini düşündürmektedir.

Anahtar kelimeler: Probiyotikler, Hipersensitivite, Laktobasiller

\section{Introduction}

Allergy, in the form of atopic diseases such as asthma, allergic rhinitis, and atopic eczema is a chronic disease, whose prevalence and significance has recently been increasing. Studies have shown that probiotic bacteriotherapy has great potential in controlling allergic diseases, and might be evaluated as a new alternative in treatment [1-3].

Probiotics are living microbial nutrient supplements that provide beneficial health effects on the host by improving 
the microbial balance. The microorganisms used as probiotics are mostly bacteria such as Lactobacillus spp., Bifidobacterium spp., Streptococcus spp., Pediococcus spp., Bacillus spp., Enterococcus spp., Propionibacterium spp., and Saccharomyces spp., and fungi such as Aspergillus spp [4]. The characteristics of probiotics are that they are man-made, safe to use in humans, they can endure low $\mathrm{pH}$ environments and bile acids, and have the ability to attach to human mucosa epithelial cells.

The beneficial effects of probiotics on immune systemmediated allergic diseases such as asthma have been reported in many in vivo and in vitro studies in recent years [4,5]. The possible mechanism for the beneficial effects of probiotics in such clinical conditions is driven by the inhibition of the in vivo immunoglobulin (Ig) $\mathrm{E}$ production. Data obtained from research support the hypothesis that nutrition with Lactobacillus spp. increases Th1 cells more than Th2 cells, and secretion of interferon (IFN)- $\gamma$, in particular, by Th1 cells might have suppressive effects on $\mathrm{IgE}$ production [5]. However, the number of studies investigating the characteristics of probiotics and clinical effects of microorganisms that form the intestinal microbiota is limited [6,7].

In the present study, we aimed to investigate the effects of a human gut flora-derived probiotic mixture prepared using isolates with described probiotic characteristics, and a standard probiotic strain Lactobacillus GG (ATCC53103) on allergy in an animal model.

\section{Materials and Method}

Isolation of the enterococcus and lactobacillus, identification of probiotic characteristics, and description tests

Stool samples of 34 healthy individuals were weighed, and diluted with sterile physiologic saline and homogenized, and diluted forms were prepared up to $10^{-7}$. A $0.1 \mathrm{~mL}$ aliquot was taken from the $10^{-5}, 10^{-6}$ and $10^{-7}$ dilution samples, and transferred to De Man, Rogosa and Sharpe agar (MRS Merck) for Lactobacillus, and to a blood agar medium for Enterococcus. Then, the samples were homogenously spread using a Drigalski spatula, and parallel seeding was performed. Growing plates were incubated in an anaerobic environment for Lactobacillus, and in an aerobic environment for Enterococcus for 48 hours at $37^{\circ} \mathrm{C}$. Gram staining was performed at the end of the incubation for the microscopic evaluation of the cream-colored, dull, S-type colonies that were thought to be compatible with Lactobacillus colony morphology and non-spore-forming Gram-positive bacillus isolates were selected. Isolates detected as Gram-positive cocci in the Gram staining preparation consisting of tiny, S-type, white or dull-colored colonies that were thought to be compatible with Enterococcus colony morphology and those that had negative catalase activity were further tested. The classic description tests and Rapid ID 32 Strep (Biomerieux, France) test kit were used in the description of the enterococci $[8,9]$.

All selected isolates were transferred to $10 \%$ Crossley Milk Medium (Oxoid) and preserved at $-80^{\circ} \mathrm{C}[8,10,11]$.

Primarily, endurance tests to bile salt and low $\mathrm{pH}$ level $(\mathrm{pH} 3.5)$ were performed for the determination of the probiotic characteristics of the isolated lactobacilli and enterococci strains. Ten lactobacilli and 3 enterococci strains (showing better growth in the presence of bile salts and at low $\mathrm{pH}$ level) that had the best probiotic characteristics were selected. First, classic description tests (production at $15^{\circ} \mathrm{C}$ and at $45^{\circ} \mathrm{C}$, formation of ammonia from arginine, and formation of gas from glucose, fermentation of various carbohydrates such as arabinose, sellobiose, melibiose, rafinose, maltose, rhamnose, saccarose, sorbitol, trehalose, mannose, mannitol, xylose, lactose, glucose), and then an

API 50 CHL (Biomerieux) test kit were used in description of lactobacilli [8,11-14].

\section{Preparation of the probiotic mixture}

We included 8 Lactobacillus plantarum, 2 Lactobacillus rhamnosus, and 3 Enterecoccus faecalis strains to the mixture, which was prepared from our own isolates, and was prepared to include $10^{9}$ cells from each live bacteria strain in the daily $0.2 \mathrm{~mL}$ skimmed milk intake medium of the mice $[4,15,16]$. A standard Lactobacillus $G G$ (ATCC 53103 ) strain was provided from Belgium, Gent University, $\mathrm{BCCM}^{\mathrm{TM}} / \mathrm{LMG}$ (Belgian Coordinated Collections of Microorganisms), and was similarly added to the mixture. The living bacteria suspensions prepared in skimmed milk were distributed into sterile glass tubes, and the tap was sealed using parafilm and stored at $-80^{\circ} \mathrm{C}$.

\section{Animal Experiment}

Forty Balb-c mice aged between 8 and 10 weeks were included in the study. The mice were kept at room temperature with 12-hour day/night illumination cycles, and 
were fed with a standard diet. The animals were divided into 4 groups, with 10 mice included in each group.

Group 1 (study group): The probiotic mixture of our own isolates, which included $10^{9}$ cells from each bacteria, was given orally in suspension for 28 days in $0.2 \mathrm{~mL}$ skimmed milk, and the mice were immunized with intraperitoneal injection of $20 \mathrm{mg} \mathrm{OVA}$ and $2 \mathrm{mg} \mathrm{AL}(\mathrm{OH})_{3}$ in $0.2 \mathrm{~mL}$ phosphate-buffered saline on days 14 and 21.

Group 2 (study group): Lactobacillus $G G$ (LGG, ATCC - 53103) standard strain that included daily $10^{9}$ cells was given orally for 28 days in $0.2 \mathrm{~mL}$ skimmed milk, and the mice were immunized through an intraperitoneal injection of $20 \mathrm{mg} \mathrm{OVA}$ and $2 \mathrm{mg} \mathrm{AL}(\mathrm{OH})_{3}$ in $0.2 \mathrm{~mL}$ phosphatebuffered saline on days 14 and 21 .

Group 3 (positive control): Skimmed milk $(0.2 \mathrm{~mL})$ was given orally each day for 28 days as a placebo, and the mice were immunized through an intraperitoneal injection of 20 $\mathrm{mg}$ OVA and $2 \mathrm{mg} \mathrm{AL}(\mathrm{OH})_{3}$ in $0.2 \mathrm{~mL}$ phosphate-buffered saline on days 14 and 21 .

Group 4 (negative control): Skimmed milk $(0.2 \mathrm{~mL})$ was given orally each day for 28 days as a placebo, and an intraperitoneal injection was administered on days 14 and 21 with sterilized phosphate-buffered saline.

The mice were sacrificed on day 28 through cervical dislocation and intracardiac blood was collected, and transferred into heparinized Eppendorf tubes. The serums were simultaneously transferred to two separate Eppendorf tubes after centrifugation, and stored at $-80^{\circ} \mathrm{C}$.

\section{Measurement of ovalbumin-specific mouse IgE antibodies using an enzyme-linked immunosorbent assay}

Ovalbumin-specific IgE levels in mice sera were studied using an allergen-specific IgE enzyme assay kit (EIA, Dr. Fooke). The enzyme conjugate of the kit was exchanged with the alkaline phosphatase (ALP)-linked at anti-mouse IgE enzyme conjugate (Southern Biotechnology), and the dilution of the conjugate was determined through experiments performed in accordance with the standards. The unknown allergen-specific $\operatorname{IgE}$ concentration in the samples was calculated with a comparison of the standards.

\section{Statistical Analysis}

The nonparametric Mann-Whitney $U$ test was used in the comparison of the OVA - specific IgE results of the mice groups. The analysis was performed based on the mean values of the groups. The Statistical Package for the Social Sciences (SPSS) was used in the statistical analysis.

\section{Results}

The mean optical density (OD) levels of the study groups fed with the probiotic mixture and control groups are shown in Figure 1. The levels in the positive control group (group 3) was detected as $605.5 \pm 159.7$, the mean OD level in the negative controls was $262.6 \pm 50.7$, the difference was statistically significant $(P<0.001)$.

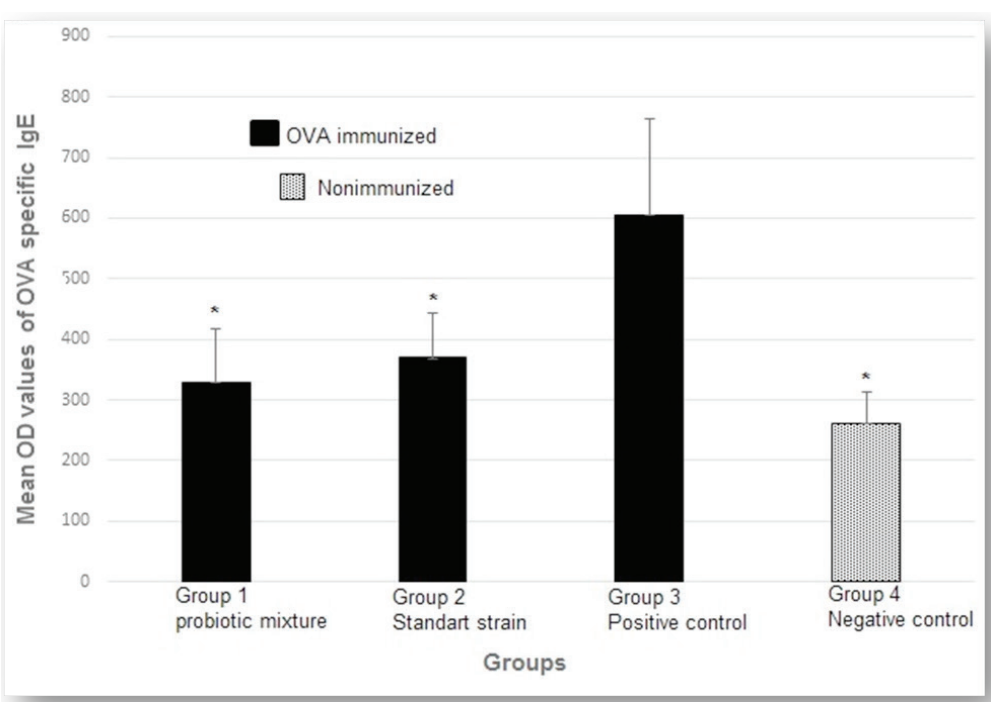

Figure 1. OVA-specific IgE levels in the study and control groups (given as mean OD value \pm standard deviation). Negative control (PBS-treated mice); positive control (OVA-sensitized mice); probiotic mixture and standard strain (oral administration with probiotic mixture and standard strain in OVA sensitized mice). Statistical significance between the positive control and each group is indicated with an asterisk $(P<0.001)$. 
Significantly lower levels of OVA-specific IgE were found in groups 1 and $2(328.6 \pm 89.2$ and $370.0 \pm 74.5$, respectively) compared with the levels $(605.5 \pm 159.7)$ of the positive controls (group 3) $(P<0.001)$. The IgE levels of the group given the probiotic mixture were lower than in the group that received the standard probiotic; however, the difference was not statistically significant $(P>0.05)$.

OVA-specific IgE levels were detected higher in groups that were given probiotic mixture and standard probiotic compared with the negative control group, which was given skimmed milk only; the difference between the groups was not statistically significant $(P>0.05)$.

\section{Discussion}

Allergens cause allergic reactions through four different routes; inhalation, digestion, contact, and injection. Researchers reported that OVA was administered through various routes such as inhalation or injection to Balb-c mice in experimental animal studies to generate an allergic reaction, it was shown that these routes resulted with OVA specific IgE levels. We used OVA through intraperitoneal injections in Balb-c mice to stimulate an allergic response [17-21].

The gastrointestinal system, which is sterile at delivery of infants and newborns, is progressively colonized by different types of microorganisms immediately after birth. In the development of allergic diseases, the close association of allergic sensitization and the gut microflora begins in the neonatal period. Recent studies showed that there were basic differences between the microfloras of infants of ceserean deliveries whose mothers used prophylactic antibiotics, and microfloras of infants of vaginal births. A significant number of infants born by ceserean sections are colonized with Bacteriodes fragilis. IgA - and IgM - secreting cells were more abundant in the circulation of infants who had B. fragilis and Bifidobacterium types. These results demonstrated that the intestinal microflora was important in the identification of individual characteristics, and changes in microflora composition might affect immunologic homeostasis [16,22,23]. The inductive role of intestinal microflora to IgE response in oral tolerance was investigated in germ free mice. In contrast to in the control group, Th2 type immune response (IgE antibody production) continued against the orally-administered OVA in the germ free mice. The destruction of oral tolerance was due to the absence of the intestinal bacterial flora $[6,7,24]$. Hessel et al., in their in vitro experimental study investigating the effects of intestinal microflora on infants with allergic diseases, detected that Gram-positive bacteria strains (Enterococcus spp., Staphylococcus spp., and Streptococcus spp.) were more effective than Gram-negative bacteria in stimulating Th1 cytokines such as IL-12 and IFNg [23]. These data suggest that Gram - positive microflora had greater significance in the reciprocal regulation of the immune system where Th2 type immune responses were more dominant in early infancy than Gram - negative microflora.

L. plantarum is a type of lactobacillus that is prominently present in the human intestinal flora and may affect endogenous strains by colonization in intestinal mucosal epithelium. In vitro animal experiments and studies showed that L. plantarum might change the interleukin profile, and inhibit antigen-stimulated $\operatorname{IgE}$ reproduction $[25,26]$. Murosaki et al., found that plasma casein-specific $\operatorname{IgE}$ levels were significantly suppressed with injections of $L$. plantarum 137, which increased the production of IL-12 from macrophages in DBA/2 mice that were fed a casein diet [27]. The results showed that the in vivo and in vitro IL-12 secretion from macrophages with L. plantarum L-137 stimulated the IFN-g production, inhibited the IL-4-induced in vitro IgE synthesis, and in addition, the presence of IL12 during antigen presentation had an inhibitory effect on Th2 responses.

The suppression of OVA-specific IgE production in the group that was given a probiotic mixture and detection of no significant difference with the group of non-immunized mice that was fed skimmed milk suggest that bacteria with probiotic characteristics in healthy human intestinal microflora might have anti-allergic characteristics.

Lactobacillus GG (ATCC 53103) is the most studied bacteria found in the human body; it was proven to be safe in humans, can remain alive in the presence of gastric acid and bile salts, and may be colonized with attachment to intestinal epithelium cells [22]. Some publications reported that Lactobacillus $G G$ decreased the symptoms of gastrointestinal inflammation and were effective in atopic dermatitis and food allergy [28]. Researchers reported that $L G G$ controlled antigen absorption by decreasing the intestinal permeability in patients with hypersensitivity, and increased the intestinal local humoral response, particularly increasing secretory IgA secretion, suppressed the increased phagocytic activity in patients with allergy, and caused degradation of milk proteins. In addition, researchers showed that $L G G$ increased the production of proinflammatory cytokines such as IL-6, IL-12, IFN- $\gamma$, 
and TNF- $\alpha$, and antiinflammatory mediators such as IL10 in in vitro mononuclear cells [29-31]. Due to all these characteristics, we preferred $L G G$ as the standard probiotic strain in the present study.

Using Lactobacillus casei shirota $(L c S)$, Matsuzaki et al., demonstrated that oral administration of $L c S$ to Balb-c mice immunized with OVA increased the production of Th-1-type cytokines such as IL-12, IL-18, IFNg, and IL-2 in spleen cells; however, it decreased the production of Th2type cytokines such as IL-4, IL-5, and IL-6 [32].

In their in vitro experimental study, Shida et al., found that heat-killed Lactobacillus casei increased the Th1-type cytokine profile and IFN- $\gamma$ in splenic cells in mice that were stimulated with OVA; however, it inhibited the total and OVA-specific IgE production by decreasing the Th2 cytokines IL-4 and IL-5 [33]. In addition, in the same study, it was found that the inhibitory effect of L. casei on $\operatorname{IgE}$ and cytokine production was associated with IL-12 levels, and macrophages responded with IL-12 production to the stimulation with L. casei.

Ivory et al., investigated the role of Lactobacillus casei shirota on seasonal allergic rhinitis, and demonstrated that there was a significant decrease in antigen-stimulated IL-5, IL-6, and IFN- $\gamma$ levels in oral LcS-administered volunteers compared with the control group, which was administered placebo; however, the specific IgG levels increased, and IgE levels decreased in the probiotic-administered group [34].

Consistent with the results of studies that evaluated the anti-allergic effects of probiotics after antigenic stimulation, we found OVA-specific IgE levels significantly lower in Balb-c mice that were immunized with OVA and administered the probiotic mixture and Lactobacillus GG compared with the control group. However, some studies suggested that probiotics might have opposite effects in addition to the studies that revealed the beneficial effects of probiotics in allergy. Lee et al [19]. investigated the immune-regulating effects of orally-administered probiotic lactobacillus for 3 weeks to Balb-c mice that were sensitized using OVA. Lactobacillus casei YIT9029 (L1), L. casei HY7201 (L2), L. brevis HY7401 (L3) or L. plantarum HY20301 (L4) were orally administered to the mice. The authors found that OVA-specific IgE levels decreased in the groups that were fed with L1, L3, and L4; however, they were significantly increased in the group fed with L2. The L3 strain developed an anti-allergic response by increasing Th1-type cytokines, and by suppressing Th2-type cytokines; however, the L2 strain increased the allergic responses.
In conclusion, the present results demonstrate that oral administration of probiotics prevents IgE-mediated OVAhypersensitivity. Nevertheless, there remains a need to clarify the immunoregulatory effects of strains with probiotic characteristics on allergy, and for more comprehensive clinical studies with wider target populations.

Acknowledgement: I would like to thank to Prof. Güner Söyletir, M.D., who is a Faculty member in the Department of Microbiology of Marmara University Medical School, for guiding us with her knowledge and recommendations in the writing of this article.

\section{References}

1. Nermes M, Salminen S, Isolauri E. Is there a role for probiotics in the prevention or treatment of food allergy? Curr Allergy Asthma Rep 2013;13:622-30. doi:10.1007/ s11882-013-0381-9

2. Prakash S, Tomaro-Duchesneau C, Saha S, Rodes L, Kahouli I, Malhotra M. Probiotics for the prevention and treatment of allergies, with an emphasis on mode of delivery and mechanism of action. Curr Pharm Des 2014;20:1025-37. doi : 10.2174/138161282006140220145154

3. Di Felice G, Barletta B, Butteroni C, et al. Use of probiotic bacteria for prevention and therapy of allergic diseases: studies in mouse model of allergic sensitization. J Clin Gastroenterol 2008;42:130-2. doi: 10.1097/MCG.0b013e318169c463.

4. Borchers AT, Selmi C, Meyers FJ, Keen CL, Gershwin ME. Probiotics and immunity. J Gastroenterol 2009;44:26-46. doi:10.1007/s00535-008-2296-0

5. Fujiwara D, Inoue S, Wakabayashi H, Fujii T. The antiallergic effects of lactic acid bacteria are strain dependent and mediated by effects on both Th1/Th2 cytokine expression and balance. Int Arch Allergy Immunol. 2004;135:205-15. doi:10.1159/000081305

6. McKenzie C, Tan J, Macia L, Mackay CR. The nutrition-gut microbiome-physiology axis and allergic diseases. Immunol Rev 2017;278:277-95. doi: 10.1111/imr.12556.

7. West CE, Jenmalm MC, Prescott SL. The gut microbiota and its role in the development of allergic disease: a wider perspective. Clin Exp Allergy 2015;45:43-53. doi: 10.1111/ cea. 12332.

8. De Man JC, Rogosa M, Sharpe ME. A medium for the cultivation of Lactobacilli. J Appl Bacteriol 1960; 23:130-38.

9. Murray PR, Baron EJ, Pfaller MA, Tenover FC, Yolken RH, (editors). Manual of Clinical Microbiology. 7th ed. Washington:ASM Press, 1999.

10. Aslım B. Lactobacillus bulgaricus ve Streptococcus thermophilus bakterilerinin metabolik ve antimikrobiyal aktiviteleri üzerine bazı fiziksel ve kimyasal mutajenlerin etkisi. G. Ü. Fen Bilimleri Enstitüsü, Doktora tezi, Ankara, 1994.

11. Çakır İ. Et tavuklarının körbağırsak florasında yer alan laktobasillerin proteolitik aktiviteleri ve organik asit 
oluşturma yeteneklerinin belirlenmesi. (Yüksek Lisans Tezi): Ankara Üniversitesi Fen Bilimleri Enstitüsü G1da Mühendisliği Anabilim Dalı,1996.

12. Thornton GM. Probiotic bacteria. Selection of Lactobacillus and Bifidobacterium strains from the healty human gastrointestinal tract: characterization of novel Lactobacillus derived antibacterial protein. $\mathrm{PhD}$ thesis. National University of Ireland, 1996.

13. Huis in't VJ, Shortt C. Selection criteria for probiotic microorganisms. In: Leeds AR, Rowland IR, eds. Gut flora and health: past, present and future. London: The Royal Society of Medicine Press Ltd, 1996:19-26.

14. Collins JK, Thornton G, O'Sullivan GO. Selection of probiotic strains for human applications. Int Dairy J 1998;8:487-90.

15. Isolauri E., Sütas Y.,Kankaanpaa P. Probiotics: effects on immunity. American Society for Clinical Nutrition. 2001;73:444-50.

16. Moreau M C, Gaboriau-Routhiau V. Influence of resident intestinal microflora on the development and functions of the intestinal-associated lymphoid tissue. In: Fuller R, Perdigon $\mathrm{G}$, editors. Chapter 3: in probiotics 3 immunomodulation by the gut microflora and probiotics. Dordrecht: Kluwer Academic Publishers, 2000.

17. Nawaz M, Ma C, Basra MA, Wang J, Xu J. Amelioration of ovalbumin induced allergic symptoms in Balb/c mice by potentially probiotic strains of lactobacilli. Benef Microbes 2015;6:669-78. doi: 10.3920/BM2014.0141.

18. Tobita K, Yanaka H, Otani H. Anti-allergic effects of Lactobacillus crispatus KT-11 strain on ovalbuminsensitized BALB/c mice. Anim Sci J 2010;81:699-705. doi: 10.1111/j.1740-0929.2010.00795

19. Jeongmin Lee, Bang J, Woo HJ. Immunomodulatory and anti-allergic effects of orally Administered Lactobacillus species in ovalbumin-sensitized mice. J Microbiol Biotechnol 2013;23:724-30. doi:10.4014/jmb.1211.11079

20. Huang J, Zhong Y, Cai W, Zhang H, Tang W, Chen B. The efects of probiotics supplementation timing on an ovalbuminsensitized ratmodel. FEMS Immunol Med Microbiol 2010;60:132-41. doi:10.1111/j.1574-695X.2010.00727.x

21. Kim H, Kwack K, Kim DY ,Eog G Ji GE. Oral probiotic bacterial administration suppressed allergic responses in an ovalbumin-induced allergy mouse model. FEMS Immunology and Medical Microbiology 2005;45: 259-67. doi:10.1016/j.femsim.2005.05.005

22. Vrese M, Schrezenmeir J. Probiotics, prebiotics, and synbiotics. Adv Biochem Engin/Biotechnol 2008;111:1-66. doi: 10.1007/10_2008_097.

23. Kirjavainen PV, Apostoluo E., Arvola T. Characterizing the composition of intestinal microflora as a prospective treatment target in infant allergic disease. İmmunology and Medical Microbiology 2001;32:1-7. doi: 10.1111/j.1574695X.2001.tb00526.X
24. Schiavi E, Barletta B, Butteroni C, Corinti S, Boirivant M, Di Felice G. Oral therapeutic administration of a probiotic mixture suppresses established Th2 responses and systemic anaphylaxis in a murine model of food allergy. Allergy 2011;66:499-508. doi: 10.1111/j.13989995.2010.02501.x

25. Schwarzer M, Repa A, Daniel C, et al. Neonatal colonization of mice with Lactobacillus plantarum producing the aeroallergen Bet $\mathrm{v} 1$ biases towards Th1 and T-regulatory responses upon systemic sensitization. Allergy 2011;66:36875. doi: 10.1111/j.1398-9995.2010.02488.x.

26. Tominaga T, Kawaguchi K, Kanesaka M, Kawauchi H, Jirillo E, Kumazawa Y. Suppression of type-I allergic responses by oral administration of grape marc fermented with Lactobacillus plantarum. Immunopharmacol Immunotoxicol 2010;32:593-9. doi:10.3109/08923971003604786.

27. Murasaki S, Yamamto Y, Ito K. Heat killed Lactobacillus plantarum L-137 supreeses naturaly fed antigen - specific IgE production by stimulation of IL-12 production in mice. J. Allergy Clin Immunol 1998;102: 57-64.

28. Cosenza L, Nocerino R, Di Scala C, et al. Bugs for atopy: the Lactobacillus rhamnosus GG strategy for food allergy prevention and treatment in children. Benef Microbes 2015;6:225-32. doi: 10.3920/BM2014.0158.

29. Pessi T, Sutas Y. Interleukin-10 generation in atopic children following oral Lactobacillus rhamnosus GG. Clinical and Experimental Allergy 2000;30:1804-8.w doi:10.1046/ j.1365-2222.2000.00948.x.

30. Thang CL, Baurhoo B, Boye JI, Simpson BK, Zhao X. Effects of Lactobacillus rhamnosus $G G$ supplementation on cow's milk allergy in a mouse model. Allergy Asthma Clin Immunol 2011;7:20. doi: 10.1186/1710-1492-7-20.

31. Kopp MV, Goldstein M, Dietschek A, Sofke J, Heinzmann A, Urbanek R. Lactobacillus $G G$ has in vitro effects on enhanced interleukin-10 and interferon-gamma release of mononuclear cells but no in vivo effects in supplemented mothers and their neonates. Clin Exp Allergy 2008 ;38:60210. doi: 10.1111/j.1365-2222.2007.02911.x.

32. Matsuzaki T, Chin J. Modulating immune response with probiotic bacteria. Immunology and Cell Biology 2000;78:67-73. doi:10.1046/j.1440-1711.2000.00887.x

33. Shida C., Makino K., Morishita A., Hachimura S. Lactobacillus casei inhibits antijen induced IgE secretion through regulation of cytokine production in murine splenocyte cultures. Int Arch Allergy Immunol 1998;115:27887. doi: 10.1159/000069458

34. Ivory K, Chambers SJ, Pin C, Prieto E, Arqués JL, Nicoletti C. Oral delivery of Lactobacillus casei shirota modifies allergen-induced immune responses in allergic rhinitis. Clin Exp Allergy 2008;38:1282-9. doi: 10.1111/j.13652222.2008.03025.x. 